\title{
Evolution of crabs - history and deconstruction of a prime example of convergence
}

\author{
Gerhard Scholtz, ${ }^{1,2}$ \\ ${ }^{1}$ Humboldt-Universität zu Berlin, Institut für Biologie, Vergleichende Zoologie, Philippstr. 13, 10115 Berlin, Germany \\ ${ }^{2}$ E-mail: gerhard.scholtz@rz.hu-berlin.de
}

Key words: Achelata, Anomala, Brachyura, carcinization, convergent evolution, morphological concepts

\begin{abstract}
Compared with the elongate bodies of shrimps or lobsters, crabs are characterised by a compact body organisation with a depressed, short carapace and a ventrally folded pleon. The evolutionary transformation from a lobster-like crustacean towards a crab is called 'carcinization' and has been interpreted as a dramatic morphological change. Nevertheless, the crab-shape evolved convergently in a number of lineages within Decapoda. Accordingly, numerous hypotheses about internal and external factors have been presented, which all try to explain these frequent convergent carcinization events despite the seemingly fundamental changes in the body organisation. However, what a crab is lies greatly in the eye of the beholder and most of the hypotheses about the lobster/crab transformation are biased by untested assumptions. Furthermore, there are two meanings of the word 'crab' within decapods: one, the phylogenetic meaning, refers to the clade Brachyura; the other, more general and typological use of the word crab, describes decapods with a certain body shape. These two meanings should not be confused when the issue of carcinization is discussed. Here, I propose a definition of what a crab is, i.e. what is meant when we speak about carcinization. I show that not all Brachyura are crabs in the typological sense. Carcinization occurred at least twice within the clade. Among Anomala there is further evidence that crab-shaped Lithodidae derived from a hermit-crab like ancestor. Carcinization is not restricted to Anomala plus Brachyura (Meiura) but is also found in Achelata, namely in slipper lobsters. A deconstruction of the crab-shape reveals that parts of it appear in various combinations among all decapod groups. Only a certain threshold of number and quality of crab-features makes us call an animal a 'crab'. This reveals that carcinization does not involve such dramatic changes in morphology as has been suggested. Moreover similar alterations of body shapes appear frequently in other crustacean taxa and in various animal groups as diverse as sharks and sea urchins. Hence morphological constraints, macroevolution, trends, tendencies, or underlying synapomorphies of any kind are not necessary assumptions for the explanation of the evolution of crabs.
\end{abstract}

\section{Contents}

Introduction: What is a crab? 87

Carcinization 89
Why is carcinization interesting? ........................................... 89

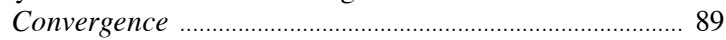

Micro-versus macroevolution ......................................... 90

Tendencies, dispositions, trends, parallelism,

underlying synapomorphy ................................................ 91

Internal or external causes? ............................................... 91

Is there a certain route towards crabs? ........................... 91

Is the crab an evolutionary success? ................................. 92

How likely is it to become a crab? .................................... 92

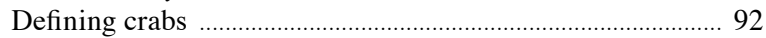

Problems with definitions .................................................. 92

What is a crab? The definition ............................................. 93

The application of this definition …………………................. 94

Brachyura, or are all crabs crabs? ..................................... 94

Anomala, multiple arrivals at the crab-shape ................. 97

Is carcinization restricted to Meiura? ............................. 100

General conclusions - deconstructing crabs ....................... 101

Resume ……....................................................................... 102

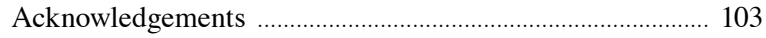

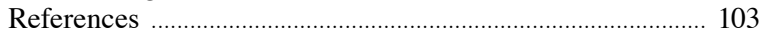

\section{Introduction: What is a crab?}

The word 'crab' carries a concept of what a crab is, based on a number of properties such as the overall shape and attributes such as sideward walking, which are related to our ideal image of a crab. However, the word crab is used with two meanings. One is the vernacular or general use describing what laypeople and scientists generally consider a crab. The other meaning relates to the monophyletic group Brachyura, the 'true' crabs as they are often called. Brachyura is a genealogical lineage that is recognised based on apomorphic characters (e.g. Jamieson, 1994; Ahyong et al., 2007; Scholtz and McLay 2009; Karasawa et al., 2011). Sometimes the two meanings of the word 'crab' match, but this is not always the case. Not everything we call a crab is a brachyuran and as is discussed in this article not every brachyuran representative is a crab. Nevertheless, the following discussion is not about language issues but rather about the classification of objects. 


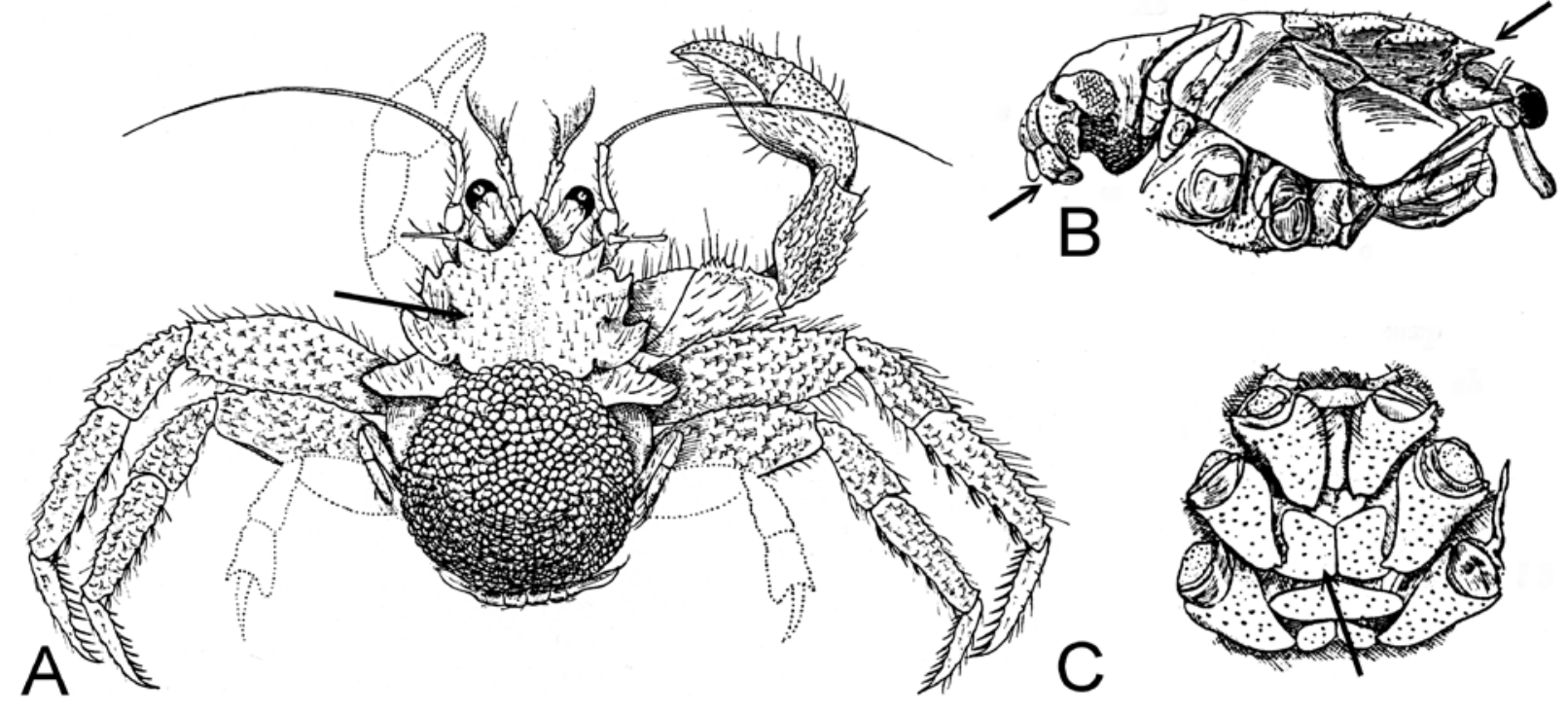

Fig.1. Carcinization exemplified by the hermit crab Porcellanopagurus after Borradaile (1916). A) Dorsal view of the habitus. The arrow points to the wide carapace. B) Lateral view (anterior to the right). The left arrow marks the reduced and ventrally flexed pleon, the right arrow points to the carapace margin. C) Ventral view of the thoracic region with the wide sterna (arrow). For a recent view of the species Porcellanopagurus edwardsi see McLaughlin and Lemaitre (1997).
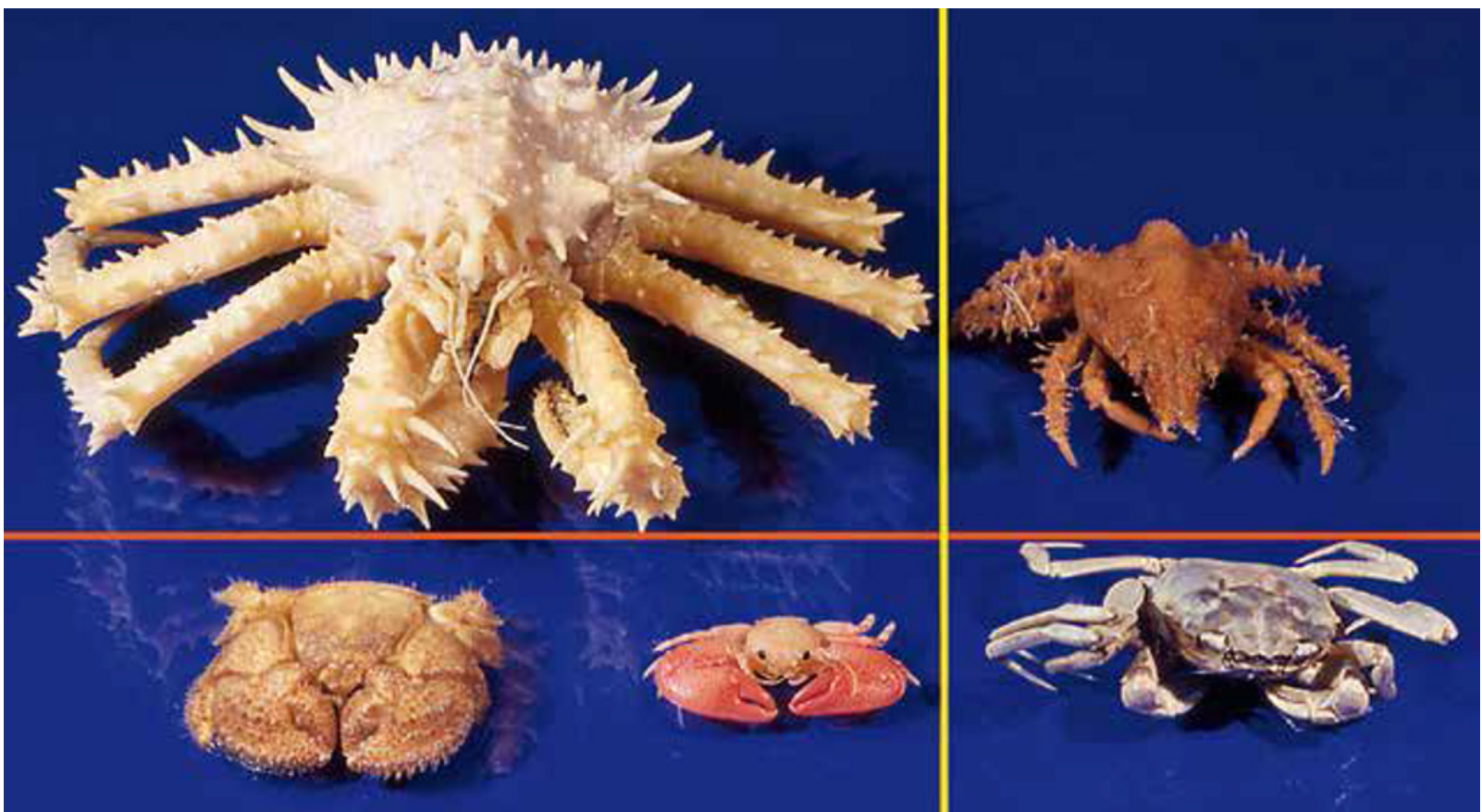

Fig. 2. Convergence of the crab-shape. The horizontal red line separates two groups which are intuitively formed based on their similar appearance. The vertical yellow line separates the clade Brachyura (right) from the clade Anomala (= Anomura) (left). 
I am aware of the fact that the vernacular use of the word 'crab' is extended to other animals with a different body shape such as hermit crabs, chelicerate horseshoe crabs, or hexapod pubic lice as 'crabs'. Likewise, the German 'Krabbe' is often used for smaller shrimps in a commercial context.

If you ask the question, 'What is a crab?' Most people would immediately consider something like the edible crab Cancer pagurus, the green crab Carcinus maenas, the Chinese mitten crab Eriocheir sinensis, or something similar to a typical crab-shaped animal. Crabs stand in contrast to long-tailed crustaceans like lobsters or crayfish, which are definitely not perceived as crabs. However, there are shapes and appearances that are not so easily categorised. These concern for instance some Majoidea or Raninoidea among the brachyurans or Hippoidea and Galatheoidea among anomalan decapods. Hence, crabs are something special, although the boundary between crabs and noncrabs is not well defined.

So what is a crab? The simple answer is, 'A crab is whatever we perceive as a crab'.

\section{Carcinization}

It is quite obvious that the crab-shape is a derived condition among decapod crustaceans and that it has evolved from an ancestor with a more elongated shape as is found in shrimps, crayfish, or lobsters (Glaessner, 1969). The shape of these long-tailed decapods can be traced back to the stem species of malacostracans (see Richter and Scholtz, 2001). Borradaile (1916) dubbed the process of the evolutionary transformation towards the crab-shape 'carcinization'. For his ideas he used the example of the hermit crab Porcellanopagurus, which shows some features that Borradaile considered as characteristic of a crab such as a flattened and widened carapace and a reduced pleon (Borradaile, 1916) (Fig. 1).

However, carcinization describing a process of evolutionary transformation leads to the problem that already the first step 'towards' a crab-like appearance might be called carcinization - even if it does not result in any creature with similarities to a crab. Hence, some authors classify crustaceans as less or fully carcinized. In accordance with this, Hiller et al. (2010) coined the term 'hypercarcinization' for an even greater and more detailed resemblance between a porcellanid (as a representative of 'false' crabs) and a brachyuran crab than is the case in other porcellanids. All this implies some finalism in that there are different degrees of success in reaching the crab-state. This finalism is already reflected in the beginning of Borradaile's article in which he spoke of 'the many attempts of Nature to evolve a crab' (Borradaile, 1916: p.111), and it can be tracked in the various concepts of carcinization developed since.

Tsang et al. (2011) suggested that the modern view of carcinization is restricted to clades outside of the Brachyura. However, the many instances of evolutionary transformations from a long-tailed cylindrical crustacean to a flattened animal with reduced and ventrally folded pleon are the interesting aspects. Thus, carcinization must have occurred in Brachyura as well, and in any case, brachyurans are the reference point for the discussion about carcinization. Hence, following Borradaile (1916) and other authors (e.g. McLaughlin and Lemaitre, 1997; Morrison et al., 2002; Anker and Paulay, 2013) the term carcinization is used here as the evolutionary transformation from a lobster-like body shape to a crab-shape, i.e., a crab is a carcinized decapod crustacean and vice versa irrespective of the phylogenetic affinities. Moreover, to avoid any teleology and because there is no definable sequence of steps that lead to a crab, carcinization is seen as 'all or nothing' phenomenon. There are no partially carcinized crustaceans, but there are decapods that show one or more properties of crabs in various combinations. Only, if certain criteria (in terms of a set of properties) are fulfilled the animal is carcinized and as such it is a crab.

\section{Why is carcinization interesting?}

\section{Convergence}

Carcinization is of interest to carcinologists and evolutionary biologists for several reasons and at different levels. First of all it is an instance of astonishing convergence, concerning a whole set of structures. This is exemplified by Fig. 2. The intuitive arrangement would recognize two groups along a horizontal line. Based on apparent similarities, the two animals in the upper row and the three in the lower row will be grouped together, respectively. However, a group formation of the specimens based on phylogenetic relationships shows a very different result. In this case the vertical line separates the two Brachyura on the right side and the three Anomala on the left side of the picture. Interestingly, the convergences of the various anomalan 

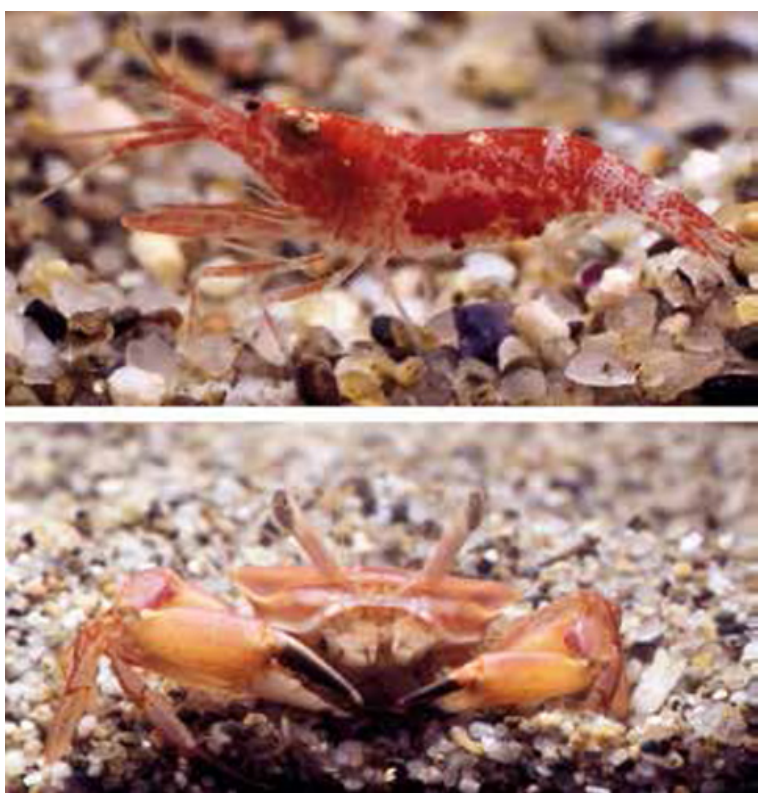

Fig. 3. The shift from a shrimp-like animal (top) to a crab-like animal (below) with seemingly dramatically different body organisation. An example of macroevolution?

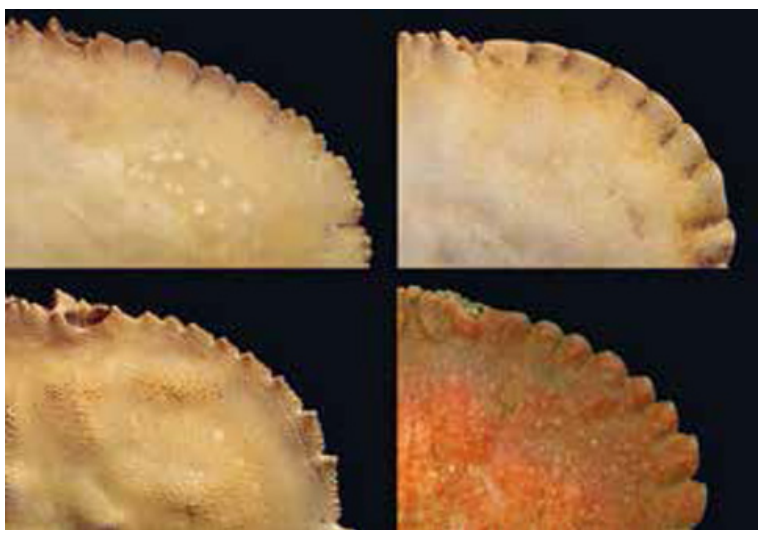

Fig. 4. The anterior right carapace margins of some cancrid crabs. An example of putative microevolution.

representatives relate even to different groups and life styles within the brachyuran crabs. For instance, the porcellanid resembles the brachyuran crabs with a round or squared carapace, whereas the lithodids are very similar to spider crabs (Brachyura, Majoidea) with a triangular and spiny carapace.

Starting with Borradaile (1916), this degree of convergence of the crab-shape led to a number of controversial speculations, ideas, and hypotheses about causes and mechanisms of carcinization. Headlines in magazine covers and titles of papers such as 'From a
Hermit to a King', 'Carcinization as an Underlying Synapomorphy, for the Decapod Crustacean Taxon Meiura', 'Carcinization in the Anomura - Fact or Fiction?', 'Mitochondrial Gene Rearrangements Confirm the Parallel Evolution of the Crab-Like Form', etc., exemplify this. The sheer number of articles touching the problem of carcinization is impressive, and it reads like the 'Who's Who' of carcinology. Still in many recent articles the concept of carcinization is addressed (Reimann et al., 2011; Tsang et al., 2011; Guinot et al., 2013; Bracken-Grissom et al., 2013; Keiler et al., 2013; Anker and Paulay, 2013). Thus, some of the various theoretical concepts of carcinization are discussed in what follows.

\section{Micro- versus macroevolution}

The crab-like shape represents a highly altered condition compared to the plesiomorphic situation in decapods with an elongate body, muscular pleon, and a tail fan formed by the uropods and the flattened telson. This kind of animal stands in stark contrast to a proper crab (Fig. 3).

All brachyuran and some anomalan crabs lost the tail-flip escape reaction and also reduced the corresponding structures such as pleon musculature and the tail fan. This change between two body organisations can be seen as an example of 'macroevolution.' Macroevolution is a greatly controversial term (see e.g. Remane, 1952; Erwin, 2000; Levinton, 2001; Kemp, 2007), and many people define it simply as evolution above the species level without any implication of special evolutionary mechanisms. Nevertheless, macroevolution is sometimes considered as a change of some sort of Bauplan, which is not caused by adaptation but internal structural factors of the group of organisms. For instance, von Sternberg (1996) applied the term Unterbauplan to characterise the difference between crabs and non-crabs. The most important proponent of this idea was Beurlen $(1930,1933)$ who used the evolution of the crab-like habit as a prime example for his theory of the sudden evolution of new types, i.e., new Baupläne, and orthogenesis based on internal factors rather than adaptation. Macroevolution stands in contrast to microevolution (Remane, 1952; Erwin, 2000; Kemp, 2007), which is restricted to evolution at the species level or which is seen to take place in little adaptive modifications in a conserved or constrained structural framework as exemplified by the lateral structures of the anterior margin of cancrid crabs (Fig. 4). The number of marginal teeth is the same; only the specific characteristics of these teeth vary. 
Tendencies, dispositions, trends, parallelism, underlying synapomorphy

These concepts are closely related to the previous one. The apparently multiple convergent achievement of the crab-shape among Anomala and in Brachyura (together Meiura, Scholtz and Richter, 1995) inspired already Borradaile (1916) to think about internal forces or constraints towards carcinization. In his article he discussed this in several places (p. 125: 'The conclusion seems inevitable that there is in the constitution of the Anomura a disposition or tendency - only the vaguest terms can be used here - to achieve that special conformation of body which constitutes a crab, and such is not the case with other Decapoda.' p. 126: 'It is with their habits rather than with their habitats that their structure is correlated.'), and ends with a sentence in which he clearly rejected Darwinian adaptationism (p. 126: 'What is bred in the bone will come out in the flesh, and Nature is no more able than Man to make silk purses out of sows' ears.'). A similar approach was used by Beurlen $(1930,1933)$ who spoke of internal tendencies towards carcinization in Anomala and Brachyura. This view is related to a more general approach, which postulates a kind of 'law' which causes the change towards morphological concentration and integration (see discussion in Remane, 1952). According to this idea, the elongate segmented body of crustaceans tends to fuse these segments and concentrates inner organs such as the nervous system ending in a compact shape like that of crabs. Morrison et al. (2002) suggested that the multiple arrivals at a crabshape within Meiura are due to parallel evolution, which is considered as an innate tendency of this group of organisms. These authors discussed two explanations for this phenomenon. One is that the crab-shape represents a key innovation conferring a large evolutionary advantage. This finalistic view was rejected by Morrison et al. (2002) because anomalan crabs are not as successful in terms of species numbers as brachyuran crabs. The other explanation, which was favoured by Morrison et al. (2002), refers to common developmental mechanisms, e.g., heterochrony, which might cause frequent carcinization in Meiura.

The argument of von Sternberg (1996) follows similar lines. He uses carcinization as an example for the concepts of 'canalized evolutionary potential' and of 'underlying synapomorphy.' According to von Sternberg (1996), several developmental features such as a set of regulatory genetic networks evolved in the lineage of Meiura, which are not morphologically expressed in the common stem species but which result in numerous independent carcinization events within Meiura.

\section{Internal or external causes?}

In contrast to these views, which postulate some kind of internal constraints of the body organisation within Meiura, there are approaches that put more stress on external selective forces that lead to crabs. Nevertheless, these arguments might also include notions of trends and tendencies. The palaeontologist Förster (1985) argued with the disadvantage of a long pleon for fast locomotion of bottom dwelling decapods, namely reptantians. Furthermore, this muscular pleon is highly attractive to predators and has to be protected. This combination of factors supposedly leads to various trends to conceal this vulnerable body part (Förster, 1985). The animals either hide the pleon in fixed structures like crevices or burrows, or they use mobile structures such as mollusc shells, or they flex the pleon underneath the body. Wägele (1989) elaborated upon this view and suggested that the convergent crab-shape was caused by the appearance of teleost fish during the Jurassic. Števčić (1971) clearly stated that carcinization (he called it with a somewhat different meaning 'brachyurization') is the adaptive product of changes in mode of life and environment, and he strictly rejected Beurlen's ideas. Nevertheless, Števčić (1971) thought along lines of 'laws' such as concentration and integration being realised in crabs and in terms of evolutionary progress, which in turn leads to evolutionary success. This is reflected in statements like 'Undoubtedly the organization of the Brachyura represents an advance over that of the other decapod Crustacea' (Števčić, 1971: p. 338).

In particular, the carcinization of lithodids, which by most authors are thought to originate from hermitcrab like ancestors is explained in terms of adaptation. The same is true for the crab-like habit of the robber crab Birgus latro (see Richter and Scholtz, 1994; McLaughlin and Lemaitre, 1997). In both cases, the adaptation to an environment lacking suitable shells has been suggested as the main factor in the evolution of these forms (see Harms, 1932; Blackstone, 1989). However, this view has been critically discussed by McLaughlin and Lemaitre (1997).

\section{Is there a certain route towards crabs?}

Many authors discussing carcinization suggest certain starting points and sequences of events that, in the end, 
result in a crab-shape. For instance, Borradaile (1916) considered the widening of the region between the bases of the third maxillipeds as the first step of carcinization. Števčić proposed that it is very probable that folding of the pleon was the first and perhaps decisive step towards a 'higher grade of organization', i.e., a crab-like shape (Števčić, 1971: p. 334). Likewise, Förster (1985) suggested that after a progressive reduction of the pleon, the compact morphology of the carapace occurred. All these ideas are based on plausible scenarios and comparisons between crabs and (not necessarily closely) related taxa, which show what the authors consider as a first step. However, if one does not think about these phenomena in terms of linear progression, the necessity of a certain character as representing a first evolutionary step towards something, which is considered as a result, dissolves.

\section{Is the crab an evolutionary success?}

Brachyuran crabs are evolutionarily highly successful in terms of numbers of individuals and species, and variety of ecological niches and lifestyles. In fact with about 7,000 species they form the largest decapod group ( $\mathrm{Ng}$ et al., 2008). This led a number of authors to suggest that the crab-shape is the key feature for this success (Števčić, 1971; Förster, 1985). However, as Morrison et al. (2002) pointed out, this evolutionary success cannot be related to the crab-shape as such since the various carcinized anomalans comprise relatively few species (a notable exception are Porcellanidae with almost 300 species). Furthermore, the question arises whether species number is an appropriate measure for evolutionary success. One could also consider the morphological diversity seen in Anomala, which is seemingly greater than that of brachyurans, as indications for success. Likewise, ecological abundance could be a measure of evolutionary performance, i.e., groups with relatively few species may nevertheless be locally ecologically dominant, as is exemplified in Eurasian freshwater crayfish. Long term survival of relatively unchanged body shapes as in lobsters might also be seen as a kind of evolutionary strategy. In any case, anomalan taxa and long tailed decapod lobsters, crayfish and shrimps exist. Hence, the crab-shape cannot be considered as being generally superior or advantageous to these other body organisations - the ecological and functional context matters.

\section{How likely is it to become a crab?}

All mentioned authors share the view that carcinization is restricted to Meiura. Moreover, brachyurans are considered as being generally carcinized whereas a number of anomalans evolved carcinization in parallel. The central question behind all these ideas, concepts, hypotheses, and speculations concerning carcinization is: how likely is it to become a crab? There are the seeming dramatic changes in morphology between the body shapes of shrimps and lobsters, on the one hand, and crabs, on the other hand; and this change contrasts with the numerous cases of carcinization. Hence, there seems a need for the explanation of this contradiction between the degree of morphological change and the frequency of its evolution. In the following sections I want to discuss, whether the morphological change towards a crab is actually that dramatic and whether it requires any of these assumption on trends or tendencies etc.

\section{Defining crabs}

\section{Problems with definitions}

With the concept of carcinization the colloquial word crab became transferred into a scientific context. If we say that carcinization is the process of becoming a crab, then the expression 'carcinized animal' is synonymous to the word 'crab'. Hence, if we take carcinization seriously, we have to think about how to define a crab.

Before the evolution towards the crab-shape can be discussed, one has to find criteria by which a crab, i.e., a carcinized decapod crustacean, can be defined. First there is the problem of every definition: if its range is too broad, it includes too many variations and it is more or less meaningless, if it is too narrow it covers just a few examples. Furthermore, it is important how specific the criteria are formulated and set or whether they are somewhat softly used. One problem, however, relates to the fact that living objects and structures underwent evolution. This includes the evolutionary transformation of structures and their substructures. Hence, when we define an organismic structure by a set of criteria we exclude structures that miss one or more aspects of this structure because they did not evolve or they became altered by evolution. As the German philosopher Nietzsche stated, 'Only something which has no history can be defined (Definierbar ist nur das, was keine Geschichte hat') (Nietzsche, 
1887 [1994]). Biological structures are the product of history. Hence, we have to apply genealogical thinking for the analysis of organismic structures and we have to deconstruct preconceived mixed concepts about structure, ontogeny, evolution, and function of characters (see Scholtz, 2010, 2013).

As mentioned above, one has to discriminate between two meanings of the word crab. One is the word crab used for a (logical) class of crustaceans that are not necessarily phylogenetically closely related but which share a set of properties and attributes concerning their habitus. This meaning allows for a definition based on characteristic features. Furthermore, it does not discriminate between 'true' or 'false' crabs - either a crustacean is a crab or it is not. The other meaning is the word crab as exemplifying representatives of the Brachyura. This meaning relates to the monophyletic group (clade) Brachyura, which is a genealogical unit established by apomorphic characters. Apomorphies, however, do not 'define' a clade; because a genealogical lineage is not definable by characters (only by its shared descent) (see Monsch, 2003; Ghiselin, 2005; Jenner, 2006; Scholtz, 2009). This is based on the relative nature of apomorphies and the fact that they can be transformed beyond recognition or even be lost within a clade; e.g., legs which are lost in snakes among the Tetrapoda, or the wings which are reduced in fleas among Pterygota. If tetrapod vertebrates were defined by the possession of four legs, snakes would have to be excluded from tetrapods; likewise if Pterygota were defined by the possession of wings, fleas would not belong to the winged insects. In both cases, the genealogical relationships allow inclusion in the larger taxon. Hence, the two meanings of the word crab should not be conflated and criteria that define a crab body shape should not be confused with apomorphies, which indicate genealogical relationships (see Scholtz, 2009).

This conflation is seen in the various attempts to define 'crab' in printed and web-based dictionaries. For instance, Webster's New Encyclopedic Dictionary (1994) defines crab as: 'A crustacean with a short broad usually flattened shell, a small abdomen curled forward beneath the body, and a front pair of limbs with strong pincers; also: any of various other crustaceans resembling true crabs having a small abdomen.' The two meanings of the word crab occur, but the Brachyura (not mentioned at all, but hidden without explanation in the 'true crabs,' which in turn seem to refer to the first part of the definition) are defined by the characters that should have been (at least partly) used for the general definition.

However, a comparable mixture of the two meanings of crab can also be found in a scientific context for instance, in Števčić's (1971) introduction of the term 'brachyurization.' He prefers it to carcinization 'because it is more general and relevant to all crabs, as a whole without regard to shape and organizational level' (Števčić, 1971: p. 333). This makes brachyurization neither a definition of a crab, nor a proper apomorphy for Brachyura. Another example of conflation of the two meanings is found in a recent article of Feldmann and Schweitzer (2010). In this article there is a chapter 'Definition of Brachyura' in which a mixture of apomorphies and plesiomorphies, mostly related to carcinization, is used to define Brachyura as a group. However, all brachyurans that lack one or more of these characteristics would not be included in the monophyletic taxon Brachyura. This is particularly true for not only (putative) stem lineage representatives, which do not yet possess all apomorphies of the crown-group, but also for extant brachyuran species that altered or lost some of the brachyuran apomorphies.

\section{What is a crab? The definition}

This discussion shows that defining a crab with a set of characters is only possible with respect to the concept of carcinization. Hence, the criteria used to define a crab are based on those aspects that were used by Borradaile (1916) to characterise carcinization. They combine the characters that apparently differ between crabs and the long-tailed decapods (Fig. 5). Accordingly, the possession of (large) claws, as stressed in some definitions is not included, because they can be found in many non-carcinized decapods as well. Furthermore, the criteria of the definition proposed here are chosen based on their clear visibility and their impact on the overall shape of the animal. I use relatively loose criteria, i.e., not mathematically exact ratios between two measures, because this would exclude a large number of cases. For instance, I have chosen the approximate ratio between length and width irrespective of the shape of the carapace in order not to exclude round, triangular, or trapezoid carapace shapes. Nevertheless, it is the purpose of a definition to exclude instances because they do not meet the criteria. Hence, any decapod crustacean that does not fulfil one of the criteria is not considered as a crab. It is also evident that this definition relates only to the result of carcinization. This definition cannot differentiate between evolutionary stages that are interpreted as 'partial' carcinization 


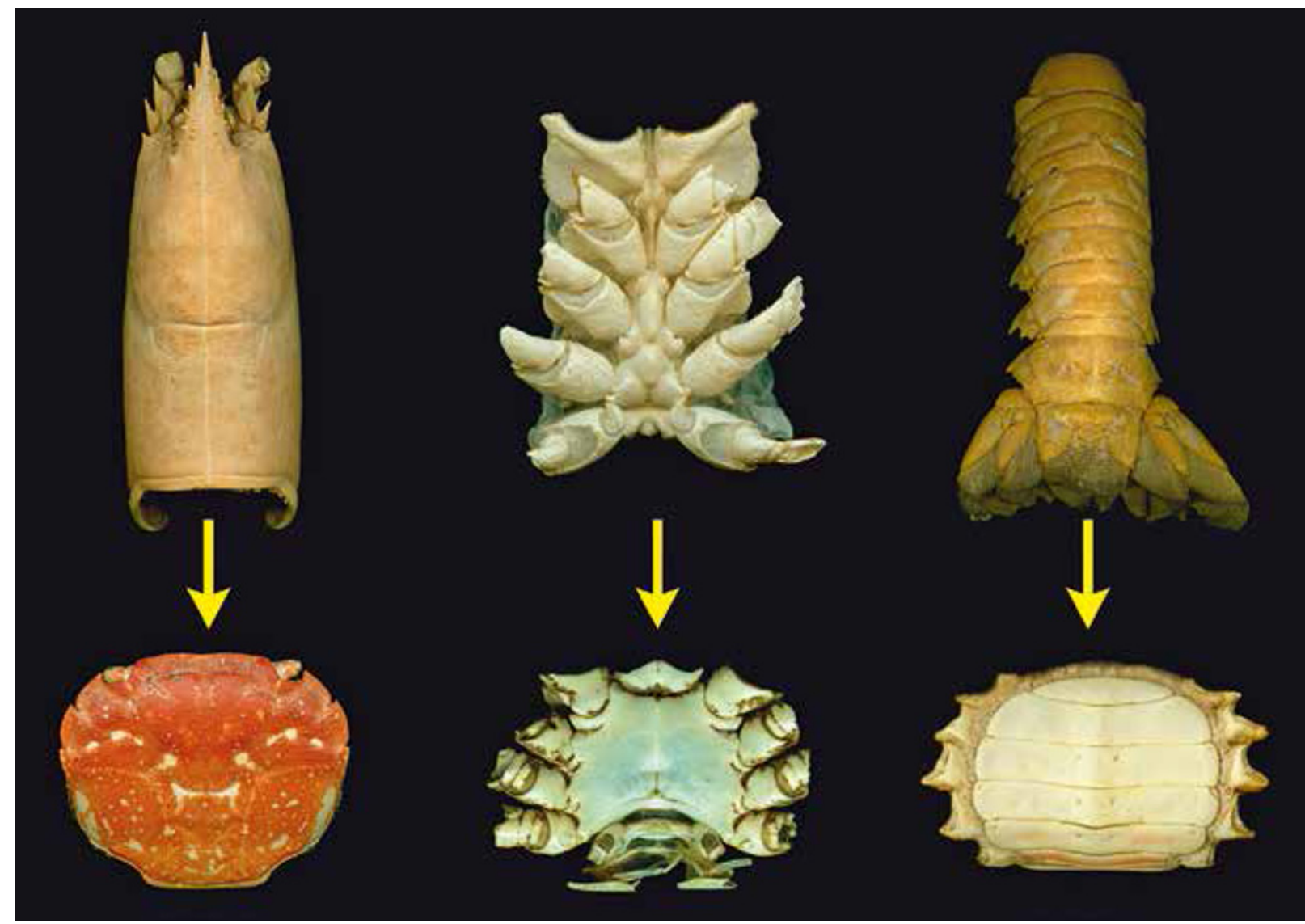

Fig. 5. Carcinization. The changes of body parts from decapods with long pleon to a crab. Left: depressing and shortening of the carapace, middle: the widening of the sternum, right: the reduction and folding of the pleon.

and the evolutionary loss of crab characters. Hence, both are not covered by the definition.

Definition: a decapod crustacean is a crab, i.e., a carcinized decapod crustacean, when the following criteria are fulfilled (see Fig. 5):

- carapace depressed with lateral margin

- carapace with similar width and length

- sternum wide

- pleon ventrally flexed

\section{The application of this definition}

\section{Brachyura, or are all crabs crabs?}

Since brachyurans are the crabs in the genealogical meaning and they are often referred to as the 'true crabs' (e.g. Morrison et al., 2002; Scholtz and McLay,
2009), the definition is first applied to representatives of this taxon (Fig. 6). Using the congruent parts of phylogenetic analyses based on morphology and molecules (Ahyong et al., 2007; Brösing et al., 2007; Chu et al., 2009; Bracken et al., 2009; Scholtz and McLay, 2009; Karasawa et al., 2011; Tsang et al., 2014) (Fig. 7), the number of evolutionary steps are discussed that are necessary to fulfil the definition of a crab.

The stem species of Brachyura was not a crab and carcinization occurred at least twice within the

\section{Brachyura}

The brachyurans that are most often seen as those with many plesiomorphic characters (e.g. Guinot, 1979, 1995; Guinot and Richer de Forges, 1995; Ahyong et al., 2007; $\mathrm{Ng}$ et al., 2008; Scholtz and McLay, 2009; Karasawa et al., 2011; Tsang et al., 2014) do not meet some of the criteria for a crab (Fig. 6). This is particularly true for species of Homolodromiidae and Homoloidea, which 


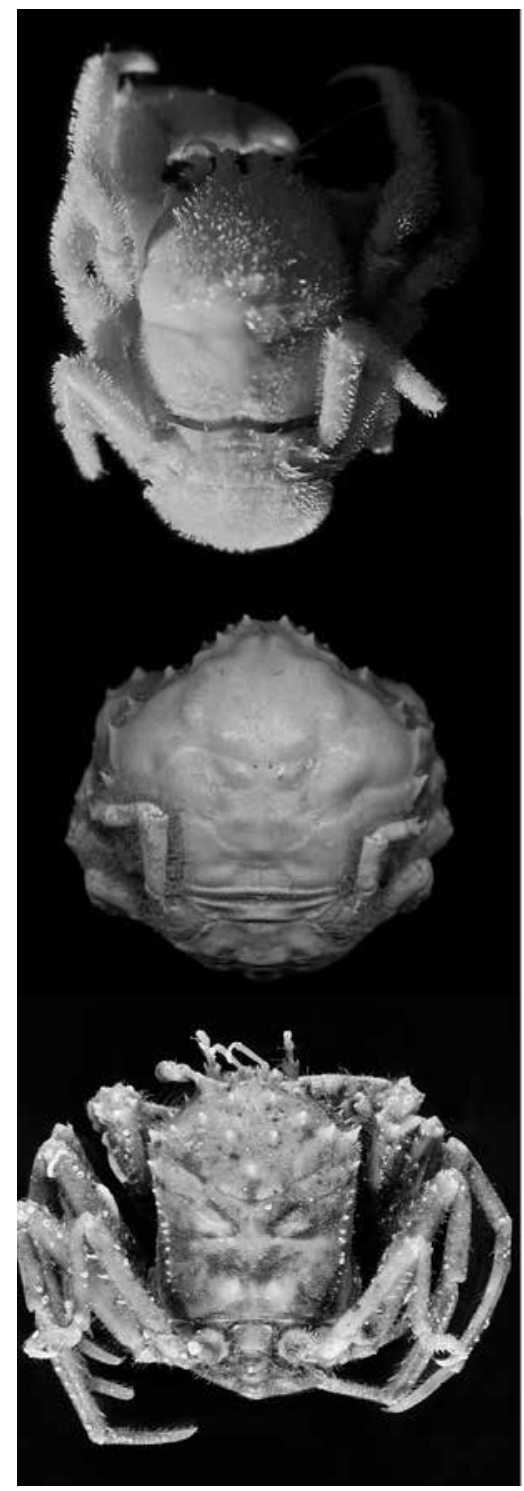

\section{Dromiacea: Homolodromiidae}

- carapace tateral margin

- carapace Elength

- wide sternum

- pleon ventrally flexed

\section{Dromiacea: Dromiidae}

- carapace with lateral margin

- carapace width = length

- wide sternum

- pleon ventrally flexed

\section{Homoloidea}

- carapace tateral margin

- carapace = tength

- wide sternum

- pleon ventrally flexed

Fig. 6. Carcinization in Brachyura.

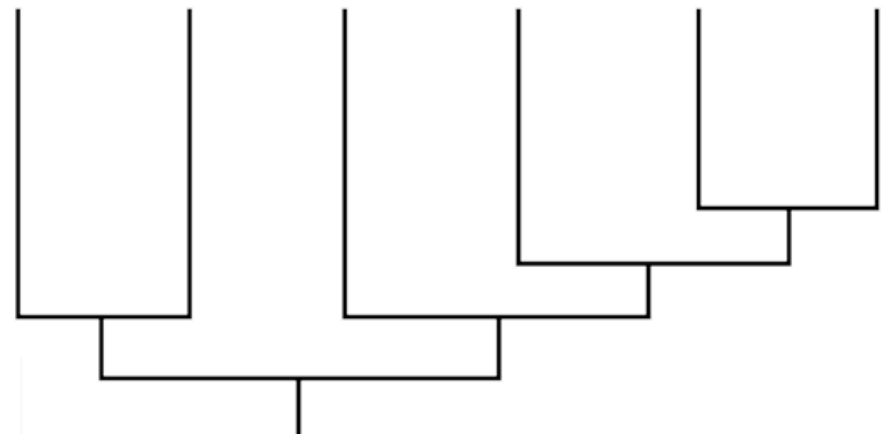

Fig. 7. Simplified phylogenetic relationships of the major brachyuran groups (based on the analyses of Ahyong et al., 2007; Brösing et al., 2007; Scholtz and McLay 2009; Karasawa et al., 2011). (For different topologies see Jamieson, 1994; Ahyong et al., 2007; Brösing et al., 2007; Guinot et al., 2013; Tsang et al., 2014). 


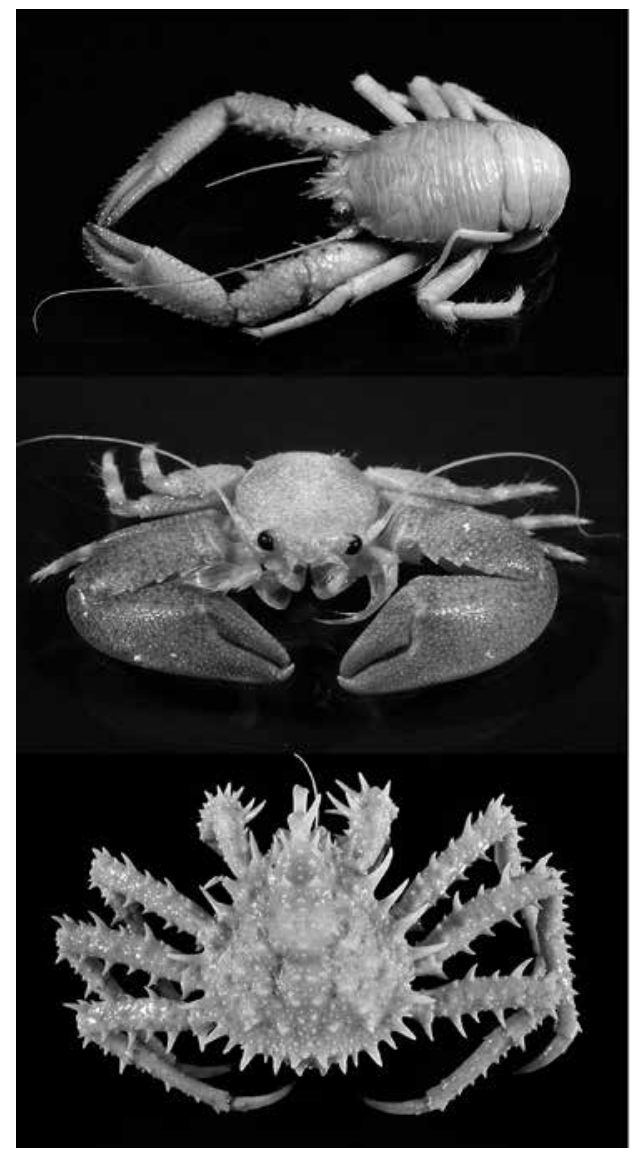

\section{Galatheidae}

- carapace tateral margin

- carapace = Tength

- wide sternum

- pleon ventrally flexed

\section{Porcellanidae}

- carapace with lateral margin

- carapace width = length

- wide sternum

- pleon ventrally flexed

\section{Lithodidae}

- carapace with lateral margin

- carapace width = length

- wide sternum

- pleon ventrally flexed

Fig. 8. Carcinization in Anomala.

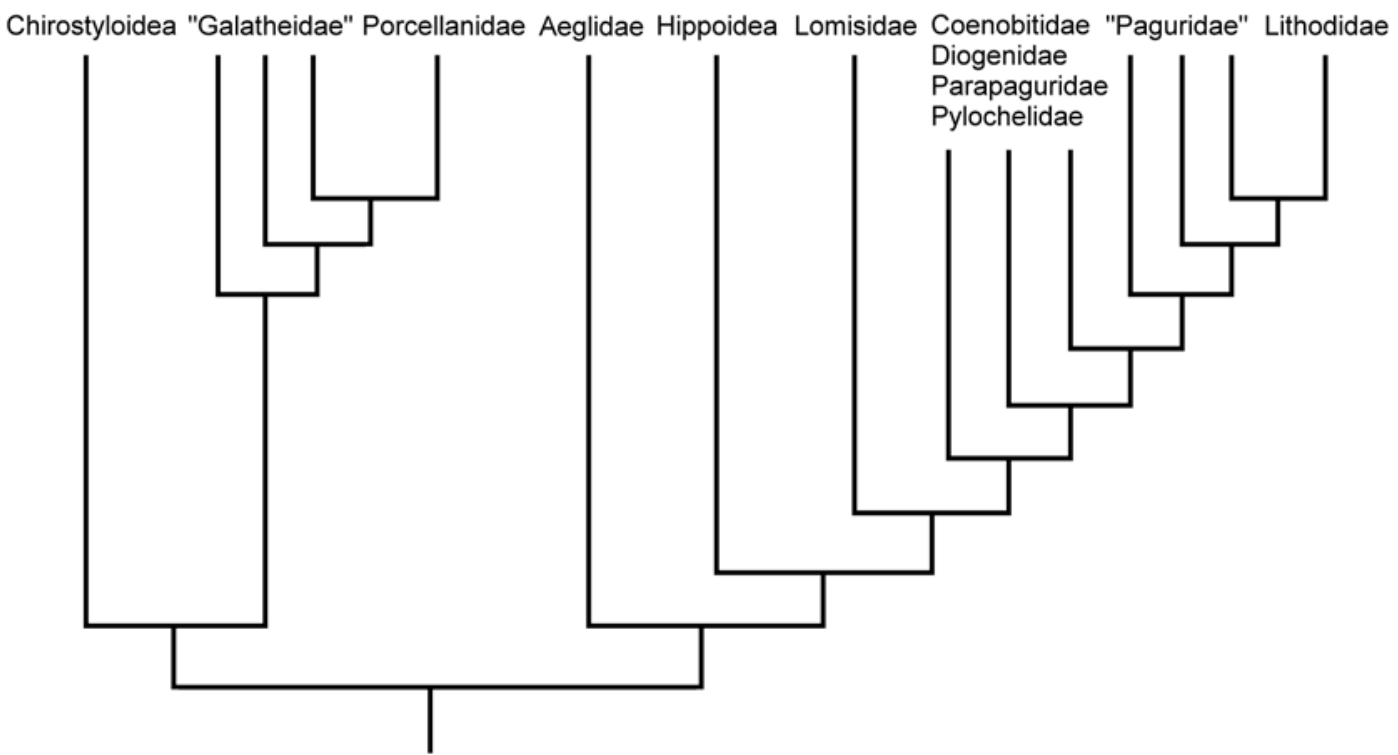

Fig. 9. Simplified phylogenetic relationships of the major anomalan groups (after Reimann et al., 2011). (For different topologies see McLaughlin and Lemaitre, 1997; Tudge, 1997; Morrison et al., 2002; Ahyong et al. 2009; Tsang et al., 2011; Bracken-Grissom et al., 2013). 
lack the short and flat carapace. Hence, according to the definition, they are not considered crabs here. It is obvious that carcinization happened within Dromiacea, i.e., Dromiidae and even more Dynomenidae look like proper crabs (Guinot and Tavares, 2003; McLay, 1999) (Fig. 6). Since Dromiidae and Dynomenidae together are likely to form the clade Dromioidea (McLay, 1999; Ahyong et al., 2007; Karasawa et al., 2011) (Fig. 7), one can conclude that carcinization evolved once in their stem lineage. With respect to the situation in homolodromiids, carcinization in dromiids and dynomenids required two steps: a shortening of the carapace and the depression forming a lateral margin of the carapace (Fig. 6). The second carcinization event in Brachyura has occurred in the lineage leading to the clade formed by Raninoidea, Cyclodorippoidea, and Eubrachyura (see Ahyong et al., 2007; Scholtz and McLay, 2009; Karasawa et al., 2011; Tsang et al., 2014) (Fig. 7). Again it is likely that two steps are involved: the shortening and the depression of the carapace. Raninoidea are included despite the fact that the Recent species display an elongated and sometimes cylindrical carapace and an almost straight pleon. However, the fossil record demonstrates that Raninoidea plesiomorphically possessed a proper crab-shape (Luque et al., 2012; van Bakel et al., 2012).

Based on the fact that homoloids and homolodromiids show a similar expression of characters concerning their body shape, one can assume that this is also the condition of the brachyuran stem species. This idea is supported by the oldest fossil brachyurans (e.g. Withers, 1932; Förster, 1979; Feldmann and Schweitzer, 2010; Schweitzer and Feldmann, 2010). Even if Eocarcinus is not considered as a brachyuran, as has been recently suggested (Feldmann and Schweitzer, 2010 contra Withers, 1932; Förster, 1979), the clearly brachyuran crab Eoprosopon klugi (Schweitzer and Feldmann, 2010) shows a similar condition, i.e., with a rather long tube-like carapace and relatively strong pleon.

Another aspect concerns the loss of crab features. There are several examples for the evolutionary loss of crab features within Brachyura. Raninoidea and Corystidae show a secondarily elongated carapace and a relatively narrow sternum, Mictyridae lack the carapace depression, and Cryptochiridae possess a relatively straight pleon (see $\mathrm{Ng}$ et al., 2008). Accordingly, these animals do not fulfil the criteria of the definition, and they are not crabs. Since it is evident that they are nested within carcinized fossil taxa or within Eubrachyura, this must be a secondary evolutionary transformation. I propose to call this loss of crab-like characters 'decarcinization'.

\section{Anomala, multiple arrivals at the crab-shape}

Since the days of Borradaile (1916), anomalans are the key example for convergent carcinization (Wolff, 1961; Türkay, 1986; McLaughlin and Lemaitre, 1997; Morrison et al., 2002; McLaughlin et al., 2004, 2007; Tsang et al., 2011; Bracken-Grissom et al., 2013; Anker and Paulay, 2013). There is no dispute that carcinization has occurred in a number of lineages within Anomala (Figs 8-9). Nevertheless, some aspects of anomalan carcinization are highly controversial. There are discussions about the number of independent carcinizations in the Anomala. This discussion, however, depends entirely on the definition of what a crab is. The most important controversy, however, is the dispute about whether Lithodidae underwent carcinization from the starting point of a pagurid hermit crab, or whether lithodids were already crab-like before hermit crabs evolved. As in Brachyura, using the congruent parts of phylogenetic analyses based on morphology and molecules, the number of evolutionary steps are discussed which are necessary to fulfil the definition of a crab (e.g. Tsang et al., 2008, 2011; Ahyong et al., 2009; Bracken et al., 2009; Chu et al., 2009; Lemaitre and McLaughlin, 2009; Reimann et al., 2011; BrackenGrissom et al., 2013) (Fig. 9).

Porcellanids and lithodids, the almost perfect non-brachyuran crabs

Here I discuss two of several instances of convergent carcinization within Anomala. One is the porcellanids, a group with a classic crab-like shape. Porcellanidae are apparently nested within paraphyletic Galatheidae (Ahyong et al., 2009; Bracken et al., 2009; Reimann et al., 2011; Bracken-Grissom et al., 2013), which are not crabs according to above definition (Fig. 8). Nevertheless, porcellanids represent an unambiguous case of carcinization - one has to look twice before its anomalan affinities are obvious (see Hiller et al., 2010) (Figs 2,8 ). However, only two evolutionary steps are required to arrive at this crab-shape with respect to the galatheid condition. In contrast to this, the lithodids, as another convincing example of carcinization, evolved all four criteria of a crab in their lineage in relation to their pagurid-like ancestor (Figs 2, 8, 10-11).

With their often spiny cuticle and their triangular carapace the anomalan Lithodidae are characterised by a body shape that strongly resembles that of Majidae among brachyurans (Figs 8, 10-12). In fact, their similarity is so great that these groups are even in a scientific context often confused. For instance, in our 

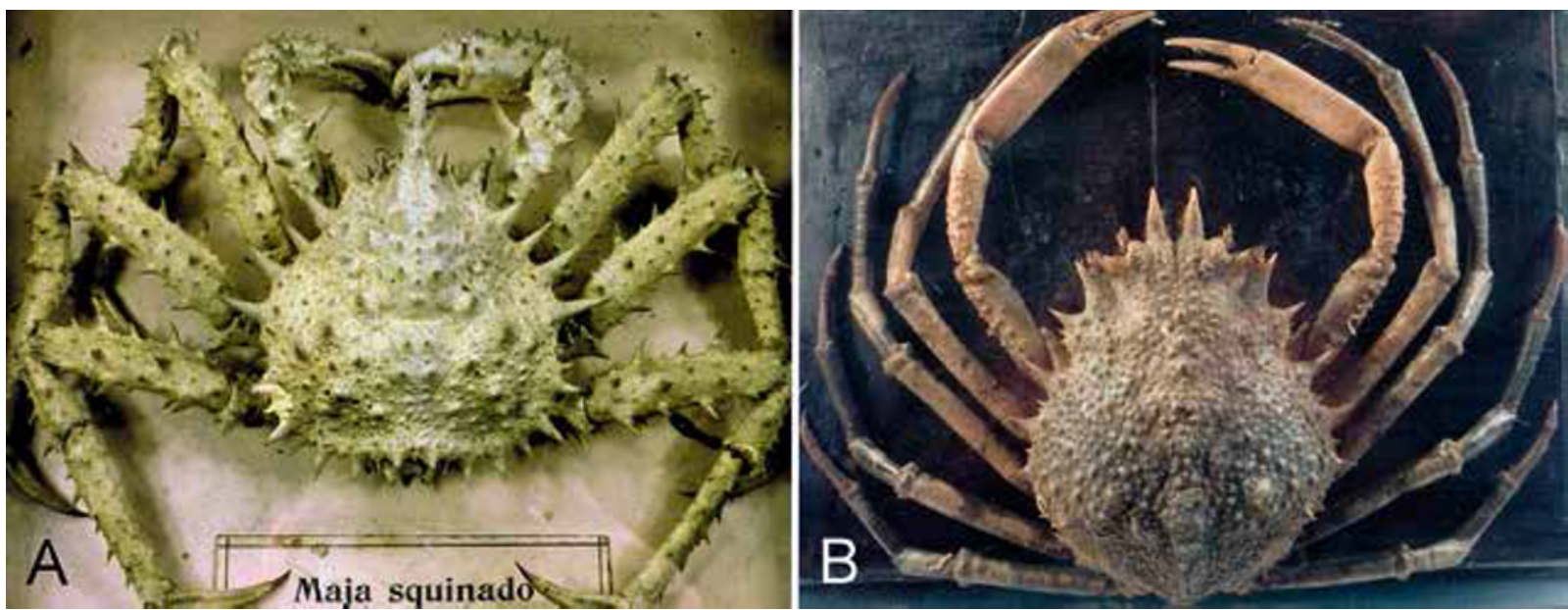

Fig. 10. Lithodes maja (wrongly labelled) (left) and Maja squinado (right). (a)
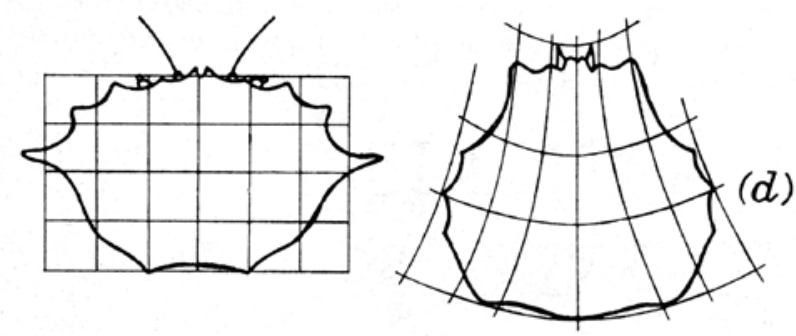

(b)
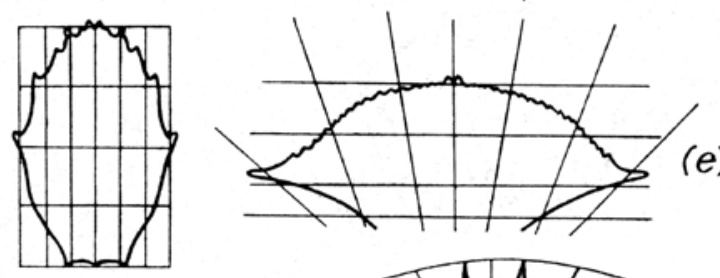

(c)
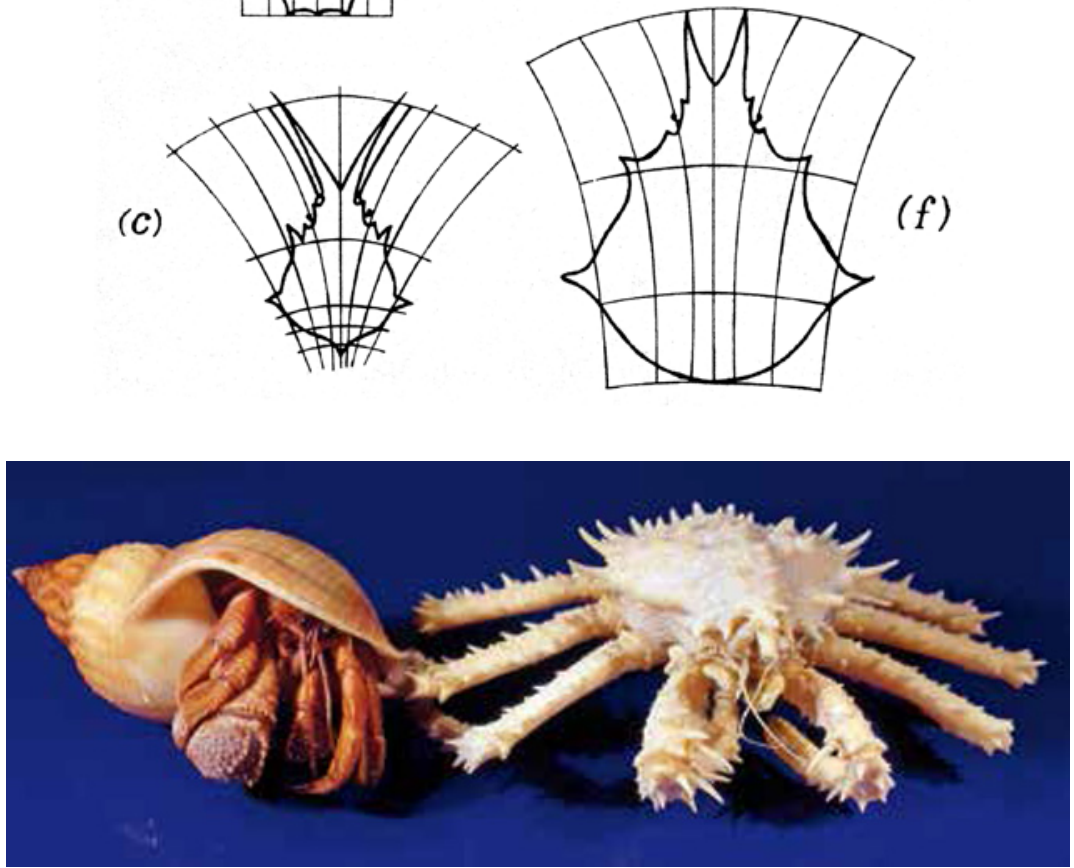

Fig. 12. The dramatic transformation from a hermit crab to a lithodid. 
zoological collection there is a dried specimen of Lithodes maja, which has long ago been labelled as Maja squinado (Fig. 8) and in the internet data base WoRMS (http://www.marinespecies.org/aphia.php? p= taxdetails\&id $=107350$, accessed $10^{\text {th }}$ September 2010) one found a picture of a species of a lithodid on the page with the data sheet of the brachyuran Maja squinado (Herbst, 1788). At some stage, both species had almost the same binominal species name i.e., Maja squinado $=$ Cancer maia Olivi, 1792, and Lithodes maja $($ Linnaeus, 1758) = Cancer maja Linnaeus, 1758 (see Neumann, 1998). In his highly influential book 'On Growth and Form' D'Arcy W. Thompson (1917) illustrated a number of carapaces of brachyuran crabs to demonstrate Cartesian transformations (Fig. 11). Compared to Geryon, a more squared crab, all representatives of the majids with their triangular carapace show converging lines at the posterior carapace margin. In contrast to this, the also triangular Paralomis shows diverging lines at the posterior carapace margin. Although Thompson erroneously includes Paralomis in the Brachyura, he serendipitously detects an interesting difference between majids and lithodids.

How can this confusion of lithodids and majids be explained? In addition to the characters listed in my definition, lithodids show some more brachyuran features that might explain this confusion. These are, the absence of uropods, and the posture of the chelae of the first pereiopods (see Figs 8, 10-11). All these characters together make lithodids extremely brachyuranlike, and it is an interesting question to test the degree of similarity at the level of internal organs like the foregut and the blood vascular system (Brösing et al., 2007; Reimann et al., 2011; Keiler et al., 2013).

\section{From a hermit to a king?}

Boas $(1880,1924)$ and Bouvier $(1894,1895)$ were the first to suggest that the crab-like lithodids had their origin from within the hermit crabs, viz. Paguridae (Fig. 12). This view has since been adopted by most researchers and has been supported by a number of morphological and molecular analyses (see Cunningham et al., 1992; Gould, 1992; Richter and Scholtz, 1994; Tsang et al., 2008; Ahyong et al., 2009; Bracken et al., 2009; Reimann et al., 2011; Bracken-Grissom et al., 2013) (Fig. 9). Nevertheless, some authors favour a different view. Martin and Abele (1986) resolved lithodids together with Lomis as sister group to all other anomalans and McLaughlin and Lemaitre (1997) suggested that lithodids are the sister group to asymmetrical hermit crabs. These authors claimed that car- cinization in lithodids is a 'fiction' (McLaughlin and Lemaitre, 1997; McLaughlin et al., 2004). Schram (2001), McLaughlin et al. (2007), and Dixon et al. (2003) suggested a close relationship of lithodids with either galatheids or hippoids. New analyses based on morphological characters such as foregut ossicles clearly resolve lithodids as being nested within pagurids (Reimann et al., 2011) congruent with basically all recent molecular studies (e.g. Cunningham et al., 1992; Tsang et al., 2008, 2011; Ahyong et al., 2009; Bracken et al., 2009; Bracken-Grissom et al., 2013). Hence, there is solid evidence that lithodids originated from a hermit-crab like ancestor.

\section{Neither the anomalan nor the meiuran stem species}

was a crab

The reconstruction of the anomalan stem species is very sensitive to the topology of internal anomalan relationships and to the chosen out group. Hence, it is quite controversial. For instance, Reimann et al. (2011) came to the conclusion that the ancestor of crown group Anomala was an elongated animal with a (partly) ventrally folded pleon. This view is supported by the oldest fossil anomalan, Platykotta akaina, which shows exactly this body shape (Chablais et al., 2011). In contrast to this, Tsang et al. (2011) suggested a crayfish- or lobster-like shape as ground pattern of Anomala. In the end, these two reconstructions were not so different, since both analyses took symmetrical hermit crabs as examples, which keep the posterior portion of their pleon in a ventrally folded position. Bracken-Grissom et al. (2013) optimised the crab-shape on their tree with a very different result. They stated that the anomalan ancestor was carcinized. This conclusion was largely based on the resolution of hippoids, which were coded as carcinized by the authors, as sister group to the remaining anomalans and the choice of carcinized brachyurans as out group (Bracken-Grissom et al., 2013). However, it is a matter of debate as to whether hippoid species are carcinized (see McLaughlin and Lemaitre, 1997; Morrison et al., 2001) and it is quite evident that brachyurans did not start as carcinized animals (see above).

Furthermore, if we consider brachyurans and anomalans together, it is likely that the common ancestor of the Meiura was not carcinized either (for a different view, see again Bracken-Grissom et al., 2013). This assumption is strengthened if fossils are included (Schweitzer and Feldmann, 2010; Chablais et al., 2011). Irrespective of the reconstruction of the anomalan or meiuran stem species, all authors agree 


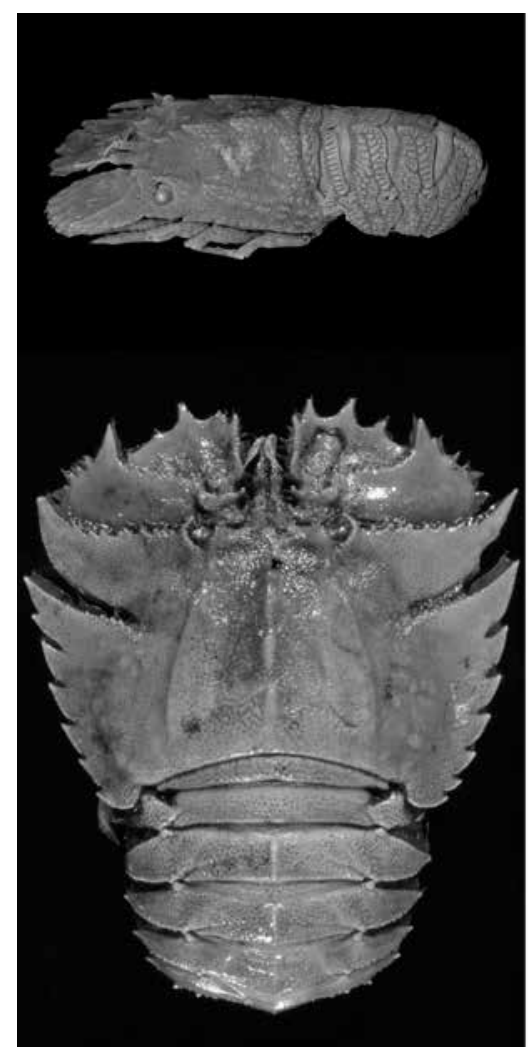

Scyllarus

- carapace with lateral margin

- carapace =length

- wide sternum

- pleon ventrally flexed

\section{Ibacus}

- carapace with lateral margin

- carapace width = length

- wide sternum

- pleon ventrally flexed
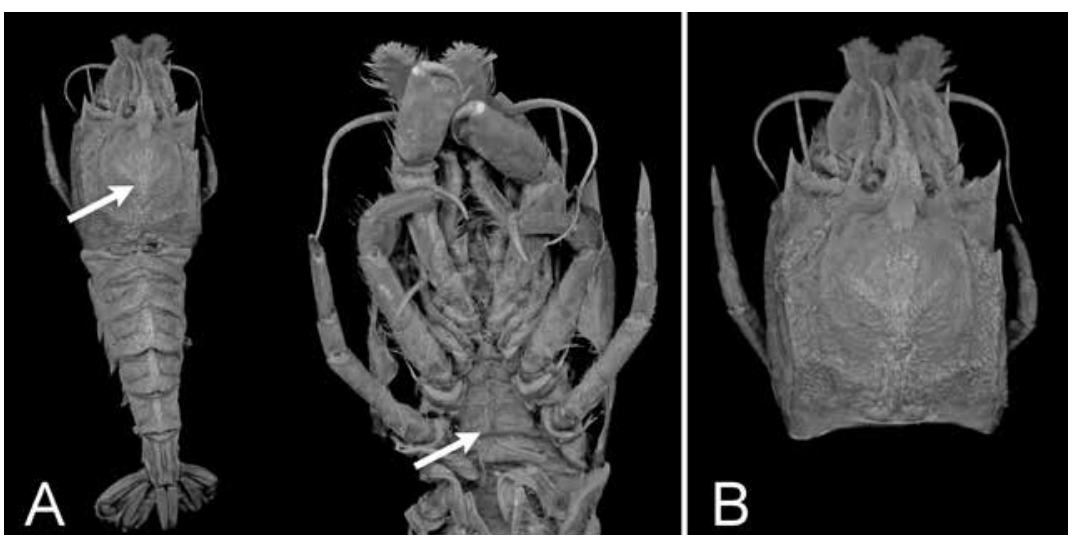

Fig. 13. Carcinization in Achelata.

Fig. 14. A crangonid shrimp with some crab-like features. A) Dorsal (left) and ventral (right) views, the arrows point to the depressed and squared carapace with a lateral margin and to the wide sternum. B) A thought experiment in which the pleon is omitted to demonstrate the crab like anterior part of the shrimp and the difficulty to reconstruct the pleon. that within Meiura, carcinization evolved in several lineages independently (Borradaile, 1916; McLaughlin and Lemaitre, 1997; Morrison et al., 2001; Ahyong et al., 2009; Reimann et al., 2011; Tsang et al., 2011; Bracken-Grissom et al., 2013). However, the status of carcinization according to the definition has been reached via different pathways, i.e., compared to the starting situation a different number of transformation steps occurred.
Is carcinization restricted to Meiura?

A sister group relationship between Anomala and Brachyura is supported by a number of molecular and morphological studies (e.g. Scholtz and Richter, 1995; Schram, 2001; Dixon et al., 2003; Ahyong and O'Mealy, 2004; Tsang et al., 2008; Chu et al., 2009; Shen et al., 2013). And most carcinologists dealing with carcinization discuss it only with respect to examples from the 
Meiura. However, one can ask whether this is appropriate. If we use the definition given above and apply it to animals among Achelata, in particular Scyllaridea, then we find some examples in which some of the criteria are met, e.g., the European slipper lobster species Scyllarus arctus (Fig. 13). In contrast to homarid lobsters and also Palinurida, the scyllarid lobsters keep their pleon in a ventrally folded position and they have a flattened carapace with a lateral margin (Fig. 13). However, the carapace is longer than wide. In dorsal view, this is even closer to the definition of a crab than what we see in homolodromiids among the brachyurans. In contrast to this, an animal like Ibacus peronii with its very wide and flat carapace in addition to the other features found in scyllarids is clearly carcinized, although it might be unusual to call Ibacus a crab (Fig. 13). Starting from a situation as in Scyllarus, to arrive at the crab-shape requires just one evolutionary alteration, namely the widening of the carapace. In any case, this is an additional instance of convergent carcinization - carcinization is not restricted to Meiura.

\section{General conclusions - deconstructing crabs}

According to the definition, a combination of less than a handful of character changes leads to the categorisation of a crustacean as a 'crab'. Some of these characters play a greater role for this categorisation than others. The short carapace and the ventrally flexed pleon appear as most important. In contrast to this, a wide sternum seems not so crucial. All these characters are allometric or topological changes with respect to the evolutionary starting situation, which has to be considered as some kind of 'macruran' decapod crustacean. This is true for the flattening, widening, and the formation of the lateral margin of the carapace, the reduction and folding of the pleon, and the widening of the sternum. However, the appearance as a crab in the various lineages did not always start from this generalised situation. As is shown above, it sometimes needs just one evolutionary step or change to attain what we call crab. This reveals that all these morphological changes do not require the assumption of some kind of macroevolutionary set of events. The morphologies of shrimps, lobsters, and crabs do not represent different Baupläne or types (for a critical view on Bauplan and types see Scholtz, 2004). Furthermore, the various instances of carcinization reveal that there is no stereotyped sequence of the steps toward the making of a crab. This stands in contrast to suggestions of Borradaile (1916),
Števčić (1971), and Förster (1985) who considered that there is a distinct order in the events of carcinization. The characters that define a crab occur alone or in various combinations in a variety of decapod groups. Even in caridean shrimps one can find a depressed carapace forming a lateral margin in combination with a more or less squared shape (Fig. 14). Only the pleon is not reduced and not folded ventrally. If we delete in a thought-experiment the pleon of this animal, we would consider the thoracic region as being of a shape that definitely allows it to be labelled as a crab (Fig. 14B). This example is relevant for the interpretation of fossils. For instance, the Lower Carboniferous Imocaris tuberculata is only known from a carapace (Schram, 2009). Imocaris has been interpreted as a dromiacean but as Schram (2009) stated, other palaeontologists doubt this conclusion. Brooks (1962) suggested that the pleon in pygocephalomorph Notocarididae is reduced and carried under the thorax as in crabs (see Irham et al., 2010 for critical discussion).

It has to be stated that crab-like characters can be lost as well, i.e., what once was a crab is now not a crab anymore. This process may be called 'decarcinization'. All this reveals that the characters making up a crab are evolutionary independent in gain and loss. A look at other crustaceans and other animals reveals similar processes as are found in carcinization.

There are many instances of animals that underwent flattening in the course of evolution, the anterior body region has been shortened, or the posterior body part has been reduced compared to the plesiomorphic situation. This kind of overall shape transformation is often found in animals that conquered benthic habitats, but similar patterns can occur under various other circumstances such as adaptation to currents, living in crevices, and parasitism.

Hence, some sort of 'carcinization' is seen in other animals. For instance, within Crustacea, several copepods, the parasitic Branchiura, and the whale lice among amphipods (Gruner, 1993) show features similar to carcinization. One particularly interesting group in this respect is the fossil Cycloidea, a putatively maxillopodan group, which has even been suggested as pre-Jurassic ecological analogues of crabs (see Schram et al., 1997; Dzik, 2008).

Outside Crustacea, rays (Batoidei) can be perceived as 'carcinized' sharks (Fig. 15). From the phylogenetic position of Rajiformes nested within the Elasmobranchii with paraphyletic sharks (Mickoleit, 2004), it is obvious that the body shape of sharks is the plesiomorphic condition and rays evolved by shortening and 

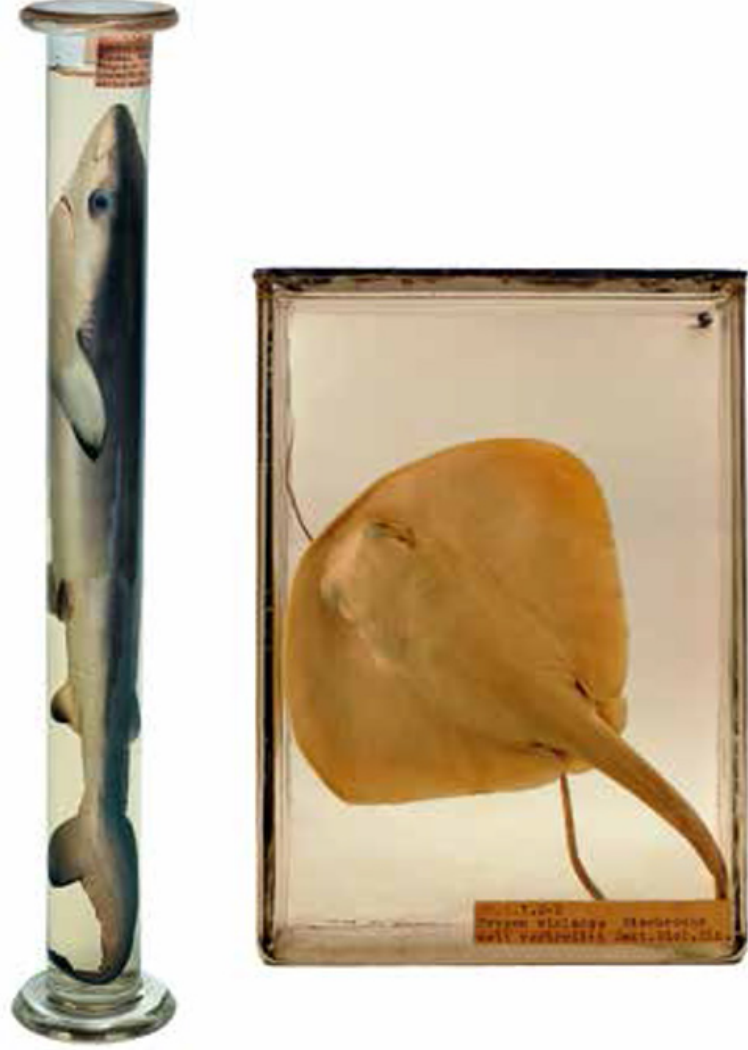

Fig. 15. Rays (right) as 'carcinized' sharks (left), see text.

flattening of the thoracic region with formation of a lateral margin. Moreover, the Squatiformes are an example for the convergent evolution of a ray-like shape among sharks. In rays the sternal region is widened as is indicated by the ventral position of the gill slits and the tail region is strongly reduced (but not ventrally folded) when compared with sharks (Fig. 15).

Something similar can be seen in a group with an entirely different body organisation such as echino-

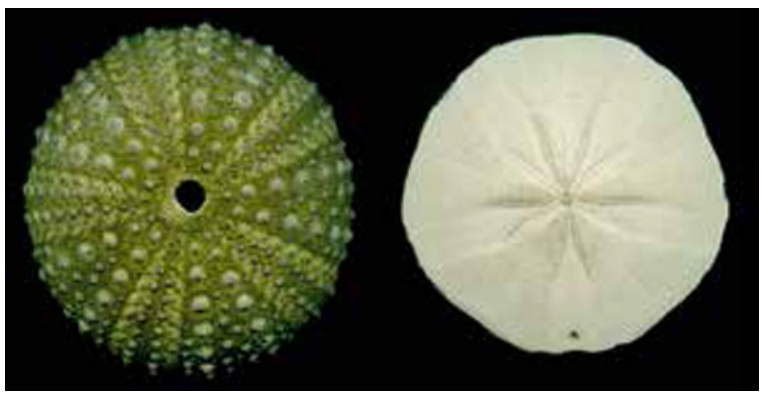

Fig. 16. Sand dollars (right) as 'carcinized' sea urchins (left), see text. derms. The sand-dollars (Clypeasteroida) among the sea urchins (Echinoida) are flattened and possess a lateral margin - similar to the changes in the crab carapace. Furthermore, the anus is shifted form the centre of the aboral side to a marginal position or even to the oral side (see Seilacher, 1979), which would be a process comparable to the ventral flexion of the pleon in crabs (Fig. 16). There are numerous other examples of flattening, margin formation, widening of the anterior body parts, and reduction of posterior body portions within the animal kingdom.

One could speculate how all these various examples can be understood as adaptations to benthic or parasitic life styles or something else in addition. For instance, in the case of the hermit-crab derived lithodids and other pagurid carcinization events, the idea has been put forward that a lack of suitable gastropod shells led to the secondary shell-less habit and thus to carcinization (see Richter and Scholtz, 1994; Anker and Paulay, 2013). Porcellanid crabs might be the evolutionary product of living under rocks and in crevices. Brachyuran carcinization might have evolved in concert with elevated posterior pereiopods carrying sponges, colonial ascidians, and other objects as camouflage. However, these scenarios are largely speculative and are beyond the scope of this essay, which deals with the morphological transformation as such.

\section{Resume}

If we ask again the initial question, 'How likely is it to become a crab?' the answer is, apparently it is pretty likely, and the fewer changes that are necessary, the more likely it becomes. Evolutionarily transmitted morphological changes of the past are the starting point for subsequent evolutionary alterations. However, it has to be stressed that these additional morphological changes do not have to occur based on special internal mechanisms; they just have occurred under certain historical circumstances. There are no partly carcinized decapods; there are only decapods with a certain set of characters, which are also found in crabs. The characters of the definition of a crab appear in various combinations and places among decapod crustaceans and in animals in general. Often it requires only one or two evolutionary alterations, which then attain a certain threshold and result in what we call 'a crab'. This falsifies the need of any specific mechanisms causing the crab-like appearance such as trends, tendencies, internal constraints, or a specific form of parallelism. 


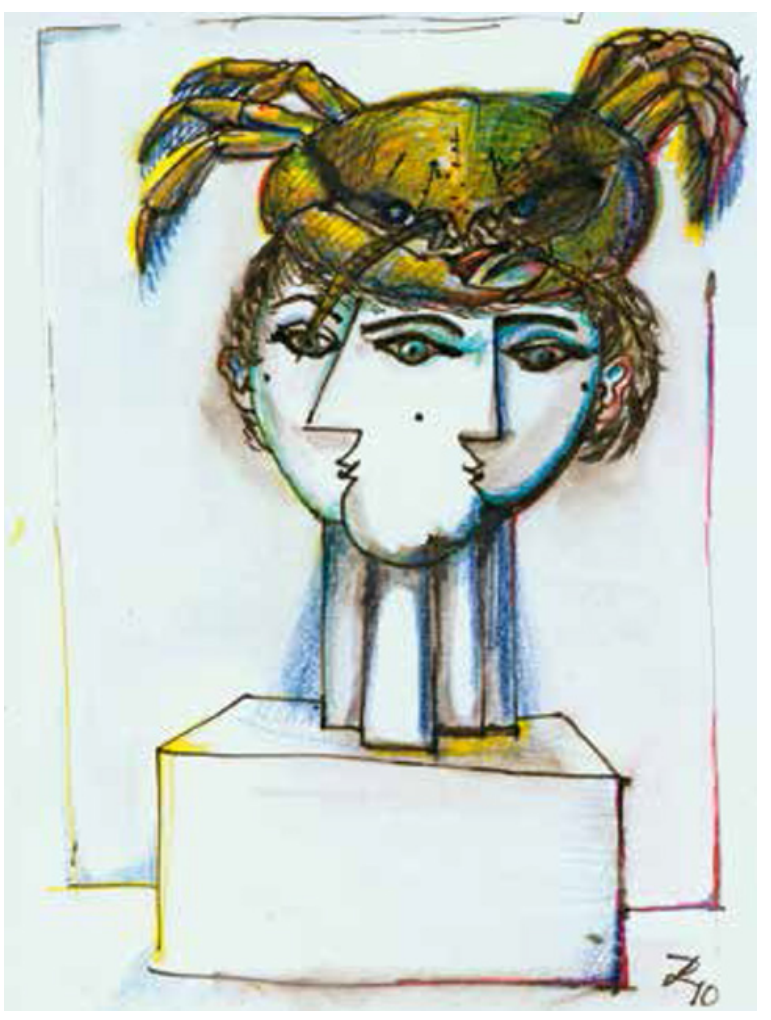

Fig. 17. Carcinization as a construct of our minds as the artist Peter Lederer sees it.

In two articles McLaughlin and co-workers (McLaughlin and Lemaitre, 1997; McLaughlin et al., 2004) asked the question whether carcinization is 'fact or fiction'? The answer is: carcinization is neither 'fact' nor 'fiction' - it is a construct of our minds (Fig. 17) based on inferred evolutionary processes. It is not a fact, because a small set of evolutionary morphological transformation is arbitrarily called a crab, once a certain level of change has been reached. It is not a fiction because these morphological changes are an evolutionary reality.

\section{Acknowledgements}

The nucleus of these ideas was presented at the $7^{\text {th }}$ International Crustacean Congress in Qingdao, China; I thank Ka Hou Chu (Hong Kong) for the invitation. The helpful comments of Colin McLay (Christchurch), Fred Schram (Seattle), and an anonymous reviewer are gratefully acknowledged. I thank Eberle und Eisfeld for the photograph of the blue shark and Peter Lederer for the 'crab in the brain' drawing. The study was supported by the Cluster of Excellence 'Image Knowledge
Gestaltung', base project 'Attention \& Form' at the HumboldtUniversität zu Berlin.

\section{References}

Ahyong ST, O’Meally D. 2004. Phylogeny of the Decapoda Reptantia: resolution using three molecular loci and morphology. Raffles Bulletin of Zoology 52: 673-693.

Ahyong ST, Lai JCY, Sharkey D, Colgan DJ, Ng PKL. 2007. Phylogenetics of the brachyuran crabs (Crustacea: Decapoda): The status of Podotremata based on small subunit nuclear ribosomal RNA. Molecular Phylogenetics and Evolution 45: 576-586.

Ahyong ST, Schnabel KE, Maas EW. 2009. Anomuran phylogeny: new insights from molecular data. Pp. 399-414 in: Martin JW, Crandall KA, Felder DL, eds, Decapod Crustacean Phylogenetics. Boca Raton: Taylor \& Francis, CRC Press.

Anker A, Paulay G. 2013. A remarkable new crab-like hermit crab (Decapoda: Paguridae) from French Polynesia, with comments on carcinization in the Anomura. Zootaxa 3722: 283-300.

Bakel BWM van, Guinot D, Artal P, Fraaije RHB, Jagt JWM. 2012. A revision of the Palaeocorystoidea and the phylogeny of raninoidean crabs (Crustacea, Decapoda, Brachyura, Podotremata). Zootaxa 3215: 1-216.

Beurlen K. 1930. Vergleichende Stammesgeschichte. Grundlagen, Methoden, Probleme unter besonderer Berücksichtigung der höheren Krebse. Fortschritte in der Geologie und Paläontologie 8: 317-586.

Beurlen K. 1933. Zur Entfaltung der Brachyuren und zur Frage der explosiven Formbildung überhaupt. Centralbatt der Mineralogie, Geologie und Paläontologie Stuttgart 1933B: 473-479.

Blackstone NW. 1989. Size, shell-living and carcinization in geographic populations of a hermit crab, Pagurus hirsutiusculus. Journal of Zoology 217: 477-490.

Boas JEV. 1880. Studier over decapodernes Slaegtskabsforhold. Det Kongelige Danske Videnskabernes Selskabs Skrifter 1, 2: 163-207.

Boas JEV. 1924. Die verwandtschaftliche Stellung der Gattung Lithodes. Det Kongelige Danske Videnskabernes Selskabs Skrifter 4: 1-34.

Borradaile LA. 1916. Crustacea. Part II.- Porcellanopagurus: An instance of Carcinization. British Antarctic ("Terra Nova") Expediton, 1910. Natural History Report 3: 111-126.

Bouvier EL. 1894. Sur la transformation des Paguriens en crabes anomoures de la sous-famille des Lithodinés. Comptes rendus hebdomadaires des séances de l'Académie des sciences Paris 119: 350-352.

Bouvier EL. 1895. Recherches sur les affinités des Lithodes \& des Lomis avec les Paguridés. Annales des sciences naturelle Zoologie 7: 157-210.

Bracken HD, Toon A, Felder DL, Martin JW, Finley M, Rasmussen J, Palero F, Crandall KA. 2009. The decapod tree of life: compiling the data and moving toward a consensus of decapod evolution. Arthropod Systematics and Phylogeny 67: 99116.

Bracken-Grissom HD, Cannon ME, A, Cabezas P, Feldmann RM, Schweitzer CE, Ahyong ST, Felder DL, Lemaitre R, 
Crandall KA. 2013. A comprehensive and integrative reconstruction of evolutionary history for Anomura (Crustacea: Decapoda). BMC Evolutionary Biology 13: 128.

Brösing A, Richter S, Scholtz G. 2007. Phylogenetic analysis of the Brachyura (Crustacea, Decapoda) based on characters of the foregut with establishment of a new taxon. Journal of Zoological Systematics and Evolutionary Research 45: 20-32.

Brooks HK. 1962. The Paleozoic Eumalacostraca of North America. Bulletin of American Paleontology 44: 163-338.

Chablais J, Feldmann RM, Schweitzer CE. 2011. A new Triassic decapod, Platykotta akaina, from the Arabian shelf of the northern United Arab Emirates: earliest occurrence of the Anomura. Paläontologische Zeitschrift 85: 93-102.

Chu KH, Tsang LM, Ma KY, Chan TY, Ng PKL. 2009. Decapod Phylogeny: What can protein-coding genes tell us? Pp. 89-99 in: Martin JW, Crandall KA, Felder DL, eds, Decapod Crustacean Phylogenetics. Boca Raton: Taylor \& Francis, CRC Press.

Cunningham CW, Blackstone NW, Buss LW. 1992. Evolution of king crabs from hermit crab ancestors. Nature 355: 539-542.

Dixon CJ, Ahyong ST, Schram FR. 2003. A new hypothesis of decapod phylogeny. Crustaceana 76: 935-975.

Dzik J. 2008. Gill Structure and Relationships of the Triassic Cycloid Crustaceans. Journal of Morphology 269: 1501-1519.

Erwin DH. 2000. Macroevolution is more than repeated round of microevolution. Evolution and Development 2: 78-84.

Feldmann RM, Schweitzer CE. 2010. Is Eocarcinus Withers, 1932, a basal brachyuran? Journal of Crustacean Biology 30: 241-250.

Förster R. 1979. Eocarcinus praecursor Withers (Decapoda, Brachyura) from the lower Pliembachian of Yorkshire and the early crabs. Neues Jahrbuch für Geologie und Paläontologie, Monatshefte 1: 15-27.

Förster R. 1985. Evolutionary trends and ecology of Mesozoic decapod crustaceans. Transactions of the Royal Society of Edinburgh 76: 299-304.

Ghiselin MT. 2005. Homology as a relation of correspondence between parts of individuals. Theory in Biosciences 24: 91-13.

Glaessner MF. 1969. Decapoda. Pp. 399-533 in: Treatise on Invertebrate Paleontology, Part R, Arthropoda 4. Lawrence: Geol. Soc. Amer. \& Univ. Kansas Press.

Gould SJ. 1992. We are all monkeys' uncles: If kings are to hermits as we are to chimps and gorillas, was Darwin wrong? Natural History 6: 14-21.

Gruner H-E. 1993. Crustacea. In: Gruner H-E, ed., Lehrbuch der speziellen Zoologie, Band I, 4. Teil. Jena: Gustav Fischer Verlag.

Guinot D. 1979. Donnèes Nouvelles sur la Morphologie, la Phylogenese et la Taxonomie des Crustacès Dècapodes Brachyoures. Mémoires du Muséum national d'Histoire naturelle. Sèrie A, Zoologie 112: 1-354.

Guinot D. 1995. Crustacea Decapoda Brachyura : Révision de la famille des Homolodromiidae Alcock, 1900. Mémoires du Muséum national d'Histoire naturelle 163: 283-511.

Guinot D, Tavares M. 2003. A new subfamilial arrangement for the Dromiidae de Haan, 1833, with diagnoses and descriptions of new genera and species (Crustacea, Decapoda, Brachyura). Zoosystema 25: 43-129.

Guinot D, Richer de Forges B. 1995. Crustacea Decapoda Brachyura: Révision de la famille des Homolidae de Haan,
1839. Mémoires du Muséum national d'Histoire naturelle 163: $155-282$.

Guinot D, Tavares M, Castro P. 2013. Significance of the sexual openings and supplementary structures on the phylogeny of brachyurans crabs (Crustacea, Decapoda, Brachyura), with new nomina for higher ranked podotreme taxa. Zootaxa 3665: 1-414.

Harms JW. 1932. Die Realisation von Genen und die consecutive Adaptation. II. Birgus latro L. als Landkrebs und seine Beziehungen zu den Coenobiten. Zeitschrift für wissenschaftliche Zoologie 140: 167-290.

Herbst JFW. 1788. Versuch einer Naturgeschichte der Krabben und Krebse nebst einer systematischen Beschreibung ihrer verschiedenen Arten. 1. Band 207-238. Berlin: Lange.

Hiller A, Viviani CA, Werding B. 2010. Hypercarcinisation: an evolutionary novelty in the commensal porcellanid Allopetrolisthes spinifrons (Crustacea: Decapoda: Porcellanidae). Nauplius 18: 95-102.

Irham M, Schram FR, Vonk R. 2010. A new species of Pygocephalomorpha (Eumalacostraca, Peracarida) from the Leitchfield Formation, Lower Carboniferous (Mississippian) of Grayson County, Kentucky, USA. Pp. 343-355 in: Fransen C, de Grave S, Ng P, eds, Studies on Malacostraca: Lipke Bijdeley Holthuis Memorial Volume. Leiden: Brill.

Jamieson BGM. 1994. Phylogeny of the Brachyura with particular reference to the Podotremata: evidence from a review of spermatozoal ultrastructure (Crustacea, Decapoda). Philosophical Transactions of the Royal Society London 345: 373-393.

Jenner RA. 2006. Unburdening evo-devo: ancestral attractions, model organisms and basal baloney. Development Genes and Evolution 216: 385-394.

Karasawa H, Schweitzer CE, Feldmann RM. 2011. Phylogenetic analysis and revised classification of podotrematous Brachyura (Decapoda) including extinct and extant families. Journal of Crustacean Biology 31: 523-565.

Keiler J, Richter S, Wirkner CS. 2013. Evolutionary morphology of the hemolymph vascular system in hermit and king crabs (Crustacea: Decapoda: Anomala). Journal of Morphology 274: 759-787.

Kemp TS. 2007. The origin of higher taxa: macroevolutionary processes, and the case of the mammals. Acta Zoologica 88: 3-22.

Lemaitre R, McLaughlin PA. 2009. Recent advances and conflicts in concepts of anomuran phylogeny (Crustacea: Malacostraca). Arthropod Systematics and Phylogeny 67: 119-135.

Levinton JS. 2001. Genetics, Paleontology, and Macroevolution, $2^{\text {nd }}$ ed. Cambridge: Cambridge University Press.

Linnaeus C. 1758. Systema naturae per regna tria naturae, secundum classes, ordines, genera species cum characteribus, differentiis, synonymus, locis. Ed. 10. Holmiae: Salvius.

Luque J, Feldmann RM, Schweitzer CE, Jaramille C, Cameron CB. 2012. The oldest frog crabs (Decapoda: Brachyura: Raninoida) from the Aptian of northern South America. Journal of Crustacean Biology 32: 405-420.

Martin JW, Abele LG. 1986. Phylogenetic relationships of the genus Aegla (Decapoda: Anomura: Aeglidae), with comments on anomuran phylogeny. Journal of Crustacean Biology 6: 576-616.

McLaughlin PA, Lemaitre R. 1997. Carcinization in the Anomura - fact or fiction? I. Evidence from adult morphology. Contributions to Zoology 67: 79-123. 
McLaughlin PA, Lemaitre R, Tudge CC. 2004. Carcinization in the Anomura - fact or fiction? II. Evidence from larval, megalopal and early juvenile morphology. Contributions to Zoology 73: 165-205.

McLaughlin PA, Lemaitre R, Sorhannus U. 2007. "Hermit crab phylogeny: a reappraisal and its "fall-out"." Journal of Crustacean Biology 27: 97-115.

McLay CL. 1999. Revision of the family Dynomenidae. Mémoires du Muséum national d'Histoire naturelle 180: 427569.

Mickoleit G. 2004. Phylogenetische Systematik der Wirbeltiere. München: Verlag Dr. Friedrich Pfeil.

Monsch KA. 2003. The use of apomorphies in taxonomic defining. Taxon 52: 105-107.

Morrison CL, Harvey AW, Lavery S, Tieu K, Huang Y, Cunningham CW. 2002. Mitochondrial gene rearrangement confirms the parallel evolution of the crab-like form. Proceedings of the Royal Society London B 269: 345-350.

Neumann V. 1998. A review of the Maja squinado (Crustacea: Decapoda:Brachyura) species-complex with a key to eastern Atlantic and Mediterranean species of the genus. Journal of Natural History 32: 1667-1684.

Nietzsche F. 1887. Zur Genealogie der Moral. Leipzig: Naumann. [English: 1994. On the Genealogy of Morality. Cambridge: Cambridge University press.]

Ng PKL, Guinot D, Davie PJ. 2008. Systema Brachyurorum: Part I. An annotated checklist of extant brachyuran crabs of the world. Raffles Bulletin of Zoology 17: 1-286.

Olivi G. 1792. Zoologia adriatica, ossia catalogo ragionato degli animali del golfo e delle lagune di Venezia. Bassano.

Remane A. 1952. Die Grundlagen des natürlichen Systems der vergleichenden Anatomie und der Phylogenetik. Theoretische Morphologie und Systematik I. Leipzig: Geest und Portig.

Reimann A, Richter S, Scholtz G. 2011. Phylogeny of the Anomala (Crustacea, Decapoda, Reptantia) based on the ossicles of the foregut. Zoologischer Anzeiger 250: 316-342.

Richter S, Scholtz G. 1994. Morphological evidence for a hermit crab ancestry of lithodids (Crustacea, Decapoda, Anomala, Paguroidea). Zoologischer Anzeiger 233: 187-210.

Richter S, Scholtz G. 2001. Phylogenetic analysis of the Malacostraca (Crustacea). Journal of Zoological Systematics and Evolutionary Research 39: 113-136.

Scholtz G. 2004. Baupläne versus ground patterns, phyla versus monophyla: aspects of patterns and processes in evolutionary developmental biology. Pp. 3-16 in: Scholtz G, ed., Evolutionary Developmental Biology of Crustacea. Lisse: Balkema Publishers.

Scholtz G. 2009. Differenzieren und Synthetisieren: Zwei Formen des Vergleichens in der Biologie. Pp. 70-78 in Fischel A. ed., Grenzbilder. Bildwelten des Wissens, Kunsthistorisches Jahrbuch für Bildkritik, Vol. 6.2. Berlin: Akademie-Verlag.

Scholtz G. 2010. Deconstructing morphology. Acta Zoologica 91: 44-63.

Scholtz G. 2013. Versuch einer analytischen Morphologie. Pp. 30-44 in: Bruhn M, Scholtz G. eds, Morphologien. Bildwelten des Wissens, Kunsthistorisches Jahrbuch für Bildkritik, Vol. 9.2. Berlin: Akademie-Verlag.

Scholtz G, McLay CL. 2009. Is the Brachyura Podotremata a monophyletic group? Pp. 417-435 in: Martin JW, Crandall
KA, Felder DL, eds, Decapod Crustacean Phylogenetics. Boca Raton: Taylor \& Francis, CRC Press.

Scholtz G, Richter S. 1995. Phylogenetic systematics of the reptantian Decapoda (Crustacea, Malacostraca). Zoological Journal of the Linnaean Society 113: 289-328.

Schram FR. 2001. Phylogeny of decapods: moving towards a consensus. Hydrobiologia 449: 1-20.

Schram FR. 2009. On the origin of Decapoda. Pp. 3-13 in: Martin JW, Crandall KA, Felder DL, eds, Decapod Crustacean Phylogenetics. Boca Raton: Taylor \& Francis, CRC Press.

Schram FR, Vonk R, Hof CHJ. 1997. Mazon Creek Cycloidea. Journal of Paleontology 71: 261-284.

Schweitzer CE, Feldmann RM. 2010 The oldest Brachyura (Decapoda: Homolodromioidea: Glaesnneropsoidea) known to date (Jurassic). Journal of Crustacean Biology 30: 251-256.

Seilacher A. 1979. Constructional morphology of sand dollars. Paleobiology 5: 191-221.

Shen H, Braband A, Scholtz G. 2013. Mitogenomic analysis of decapod crustacean phylogeny corroborates traditional views on their relationships. Molecular Phylogenetics and Evolution 66: 776-789.

Sternberg R von. 1996. Carcinization as an underlying synapomorphy fort the decapod crustacean taxon Meiura. Evolutionary Theory 11: 153-162.

Števčić Z. 1971. The main features of brachyuran evolution. Systematic Zoology 20: 331-340.

Thompson DW. 1917. On Growth and Form. Cambridge: Cambridge University Press.

Tsang LM, Ma KY, Ahyong ST, Chan T-Y, Chu KH. 2008. Phylogeny of Decapoda using two nuclear protein-coding genes: Origin and evolution of the Reptantia. Molecular Phylogenetics and Evolution 48: 359-368.

Tsang LM, Chan T-Y, Ahyong ST, Chu KH. 2011. Hermit to king, or hermit to all: multiple transitions to crab-like forms from hermit crab ancestors. Systematic Biology 60: 616-629.

Tsang LM, Schubart CD, Ahyong ST, Lai JCY, Au E, Chan T-Y, Ng PKL, Chu KH. 2014. Evolutionary history of true crabs (Crustacea: Decapoda: Brachyura) and the origins of freshwater crabs. Molecular Biology and Evolution. doi: 10.1093/ molbev/msu068

Tudge CC. 1997. Phylogeny of the Anomura (Decapoda Crustacea): Spermatozoa and spermatophore morphological evidence. Contributions to Zoology 67: 125-141.

Türkay M. 1986. Crustacea, Decapoda, Reptantia der Tiefsee des Roten Meeres. Senckenberg Maritima 18: 123-185.

Wägele JW. 1989. On the influence of fishes on the evolution of benthic crustaceans. Zeitschrift für zoologische Systematik und Evolutionsforschung 27: 297-309.

Webster's New Encyclopedic Dictionary 1994. Cologne: Könemann.

Withers TH. 1932. A Liassic crab, and the origin of the Brachyura. Annals and Magazine of Natural History Ser. 10, 9: 313-323.

Wolff T. 1961. Description of a remarkable deep-sea hermit crab, with notes on the evolution of the Paguridea. Galathea Report 4: 11-32.

Received: 16 December 2013

Revised and accepted: 24 January 2014

Published online: 26 March 2014

Editor: J.W. Arntzen 